\title{
Studi Komparatif Kitāb Rijāl Sunni dan Syiah (Studi atas Kitāb Tadzkirah al-Huffāzh Karya al-Dzahabi dan Kitāb al-Rijāl Karya Dāwud al-Hulli)
}

\author{
Rohmansyah \\ Universitas Muhammadiyah Yogyakarta \\ rohmansyah@umy.ac.id
}

DOI: http://dx.doi.org/10.29240/alquds.v1i2.237

Submitted: 2017-08-08| Revised: 2017-11-23| Accepted: 2017-12-01

\begin{abstract}
Comparative Study of Kitāb Rijāl Sunni and Shīah (Study on the Kitāb Tadzkirah al-Huffāzh of al-Dzahabi and Kitāb al-Rijāl of Dāwud al-Hulli). Study the book of Hadith is a great importance to study, especially the study of rijal alhadith, such as Tadzkirah al-Huffazh of al-Dzahabi, Sunni versions, and Kitäb al-Rijäl of al-Hulli, Syi'i version. This research was conducted with descriptive analytical approach and historical approach. This study found that both books discuss the rijal al-hadith (the narrators of hadith) from the aspect of quality that is structured in the systematic style of the book of Mu'jam. The difference is that the Sunni rijāl al-Hadits are the companions of the Prophet, the tabi'in and so on, while the Shi'ite rijal al-hadith is the Abl al-Bait which is attributed to the figure of Ali bin Abi Talib. Historically, the two books are composed from the historical background behind it. The Book of Tadzkirah al-Huffazh is structured as an attempt to legitimize narrators and memorizers of Hadith from amongst shahabah, tabi'in, and so on. Meanwhile, the Kitāb al-Rijāl version of the Shi'ah also wanted to prove the greatness of their companions from the ahl al-Bait people attributed to Ali ibn Abi Talib.
\end{abstract}

Keywords: kitab al-Rijal, kitāb Tadzkirah, comparative study

Abstrak: Studi kitab hadis menjadi suatu hal yang sangat penting untuk dipelajari
terutama studi kitab rijäl al-badìts, yakni kitab Tadzkirah al-Huffazh karya al-Dzahabi
versi Sunni dan Kitāb al-Rijāl karya al-Hulli versi Syi'i. Penelitian ini menggunakan
pendekatan deskriptif-analitis dan pendekatan historis. Penelitian ini menemukan
bahwa kedua kitab tersebut sama-sama membahas rijäl al-hadìts (para periwayat hadis)
dari aspek kualitas yang disusun dengan gaya sistematika kitab Mu’jam. Perbedaannya,
rijāl al-Hadīts versi Sunni adalah para sahabat Nabi, tabi'in dan seterusnya, sedangkan
rijäl al-haditts versi Syi’ah adalah Ahl al-Bait yang dinisbatkan kepada sosok Ali bin Abi
Thalib. Secara historis kedua kitab tersebut disusun tidak lepas dari sejarah silam yang
melatarbelakanginya. Kitab Tadzkirah al-Huffazh disusun sebagai upaya legitimasi
terhadap tokoh periwayat dan penghafal hadis dari kalangan sahabat, tabi'in, dan
seterusnya. Sementara, Kitāb al-Rijāl versi Syiah juga ingin membuktikan kehebatan 
para sahabat mereka dari kalangan ahl al-Bait yang dinisbatkan kepada Ali bin Abi Thalib.

Kata kunci: kitab al-Rijal, kitāb Tadzkirah, studi komparatif

\section{Pendahuluan}

Studi kitab hadis adalah hal penting untuk mengetahui biografi tokoh ${ }^{1}$ dan para periwayat hadis, terutama kajian kitab rijal yang mengandung beberapa lapisan (tabaqah) yang berkaitan dengan historiografi. ${ }^{2}$ Mengumpulkan hadis, menemukan, mengadakan perjalanan untuk mencari hadis, dan membukukan dari hasil penyusunannya merupakan dasar pertama kebudayaan bangsa Arab Islami, ${ }^{3}$ dengan segala ilmu yang dikutip dan disandarkan kepada periwayatan serta dipercayakan kepada sanad. Kodifikasi hadis ini adalah suatu yang krusial dalam studi hadis yang waktunya cukup lama dari beberapa peristiwa sehingga perlu metode-metode keotentikan hadis dan evaluasi kritis. ${ }^{4}$ Dengan demikian sejarah dan perilaku, peperangan dan penaklukan, biografi dan thabaqah (lapisan) itu semuanya berasal dari kodifikasi dan periwayatan hadis. ${ }^{5}$

M. Alfatih Suryadilaga mengatakan dalam kata pengantarnya, bahwa sejarah panjang penghimpunan (pentadwinan) hadis bukanlah merupakan pelalaian terhadap hadis. Keberadaan hadis telah didudukkan oleh para sahabat dengan baik. Mereka sangat hati-hati dalam mengambil dan menetapkan hadis sebagai hujjah. Penyebaran hadis masa sekarang tidak begitu luas pada masa sebelumnya sejak dibukukan secara resmi oleh khalifah Umar bin Abdul Aziz

${ }^{1}$ Biografi tokoh dapat diketahui dengan mengkaji studi kitab hadis karya para ulama klasik maupun kontemporer. Dengan hal itu akan diketahui biografi tokoh hadis, pemikiran dan sistematika kitab hadis. Banyak para ahli yang konsen dalam kitab melakukan penelitian kajian kitab hadis. Lihat Agusni Yahya, "Pendekatan Hermeneutik dalam Pemahaman Hadis (Kajian Kitab Fath Bari karya Ibnu Hajar al-Asqalani), dalam Jurnal Ar-Raniry: International Journal of Islamic Studies, Vol. 1, No. 2, Desember 2014, 365-378. Rohmansyah, "Konsep Jihad dalam Kutub at-Tis'ah (Studi Maudhui)" dalam Jurnal Al-Majaalis, Vol. 3, No. 2, Mei 2016, 35.

2 Marwan Shalahudin, "Historiografi Ulama Klasik dalam Tabaqat" dalam Jurnal Kalimab Vol. 12, No. 1, Maret 2014, 139.

3 Budaya Arab Imam Malik sampai masa al-Bukhari dan Muslim serta generasi setelahnya banyak melakukan perlawatan dalam rangka pencarian hadis hingga ditemukan hadis yang bersumber dari Rasulullah. Namun tidak semua hadis yang ditemukan shahih sehingga perlu melakukan penelitian dengan menggunakan kitab rijal hadis sebagaimana yang dilakukan Mustafa Azami dalam bukunya Memahami Ilmu Hadis: Telaah Metodologi dan Literatur Hadis. Lihat Mustafa Azami, Memahami Ilmu Hadis: Telaah Metodologi dan Literatur Hadis, terj. Meth Kieraha (Jakarta: Lentera, 2003), 41 dan 129.

${ }^{4}$ Kamaruddin Amin,” The Reliability Of The Traditional Science Of Hadith: A Critical Reconsideration" dalam Jurnal Al-Jami’ah, Vol. 43, No. 2, 2005, 256.

${ }^{5}$ Subhi Shalih, Membahas Ilmu-ilmu Hadis, terj. Tim Pustaka Firdaus Jakarta, Pustaka Firdaus, 2013), 311. 
pada abad ke-2 hijriyah. Mulai dari sini perjalanan pembukuan hadis di dunia Islam sudah berjalan sekitar 12 abad lamanya. ${ }^{6}$

Dalam konteks keindonesiaan juga banyak peminat melakukan research kajian kitab karya ulama hadis Indonesia, seperti Mustafa Ali Yaqub ${ }^{7}$, Saleh Darat $^{8}$, dan lain-lain. Kajian kitab thabaqah adalah hal yang penting dikaji karena kitab ini salah satu yang mewarnai budaya Islam pertama kali yang muncul akibat adanya pembukuan hadis dan pengumpulan riwayat. Di dalamnya akan diketahui biografi para perawi dan keadaan mereka masa demi masa, dan tingkatan demi tingkatan. Kitab-kitab thabaqah yang terkenal adalah kitab alThabaqâhal-Kubrâ karya Ibnu Sa'ad, kitab Thabaqah al-Qurâ'i karya Abu Amr alDani, kitab Thabaqâh al-Syâfi'i al-Kubrâ karya Abd al-Wahb al-Subki dan terakhir kitab Tad₹kirat al-Huffä̧h karya al-Dzahabi.

Untuk mengetahui lebih dalam mengenai kajian kitab hadis, penulis akan mencoba melakukan sebuah kajian yang difokuskan pada kitab Tadzkirah alHuffä̧̧ karya al-Dzahabi versi Sunni dan mengkomparasikannya pada Kitāb alRijal karya al-Hulli versi Syiah. Rumusan masalah dalam tulisan ini yaitu: 1) bagaimana sistematika penyusunan dua kitab Rijal al-Hadis tersebut baik versi Sunni maupun Syi'ah?, (2) bagaimana perbedaan dan persamaan dua kitab tersebut?, (3) bagaimana refleksi dari kajian studi kitab dari dua kitab Rijal alHadis tersebut?. Tujuannya adalah untuk mengetahui tentang sistematika, perbedaan dan persamaan serta refleksi kajian dalam tradisi keilmuan hadis. Metode penelitian yang digunakan adalah metode pendekatan deskriptif-analitis dan melakukan refleksi kajian dalam tradisi keilmuan dengan menggunakan pendekatan historis.

\section{Kitab Tadzkirah al-Huffāzh}

Kitab Tadzkirah al-Huffä̧̧ merupakan karya Imam al-Dzahabi adalah seorang hafidz, dengan nama lengkap Muhammad bin Ahmad bin Qaimâz bin Abdillah, al-Tarkimâni al-Ashal Al-Fariqi al-Damsyiqi, Abu Abdillah Syamsuddin al-Dzahabi. Dia dijuluki dengan sebutan Syaikh al-Imam al-Hâfidz al-Kabîr, Mu'arih al-Islâm, Syaikh al-Muhaditsin, Muhadits al-Ashar, Khatimah al-Huffadz, Syamsuddin, Abu Abdillah. Ibnu Hajar al-Asqalâni menyebutkan

${ }^{6}$ M. Alfatih Suryadilaga (ed), Studi Kitab Hadis (Yogyakarta: Teras, 2009), ix.

${ }^{7}$ Rohmansyah, "Hadith Hermeneutic of Ali Mustafa Yaqub" dalam Jurnal Kalam, Vol. 11, No. 1, Juni 2017, 187-214.

8 Mudzakiron dan Arid Chasanatul Muna, "Pola Redaksi Matan Hadis dalam Kitab Majmû'ah al-Syarî̀ah Karya K.H. Saleh Darat" dalam Jurnal RELIGIA, Vol. 18, No. 2, September 2015, 43-227.

${ }^{9}$ Mahmud Thahan, Taisir Musthalah al-Hadits (Beirut: Dar al-Fikr, t.t),191. 
dalam kitab “Al-Dirar al-Kâminab”tentang biografinya secara ringkas. Ia lahir di Damsyiq (Damaskus), pada tanggal 03 Rabi'ul Akhir tahun $673 \mathrm{H}^{10}$

Adapun keluarganya berasal dari keturunan Tarkimaniyah yaitu suatu tempat yang bernama Miyâfariqîn, salah satu negeri yang terkenal dengan sebutan Diyâr Bakr, kemudian pindah ke Damsyiq dan tinggal di sana. Ayahnya adalah Ahmad, ia seorang muallaf, seorang pengrajin emas dan kakeknya bernama Ustmân seorang muallaf juga yang selalu menyibukan dirinya dengan berdagang. Sebagian waktunya ia gunakan untuk mencari ilmu. ${ }^{11}$

Perkembangan ilmu al-Dzahabi sangat luar biasa, dan ini terbukti dia mengajar anak-anak hingga tingkatan syaikh yang jumlahnya kurang lebih mencapai 200 ribu orang. ${ }^{12}$ Pada waktu berusia 18 tahun, al-Dzahabi sudah mulai menuntut ilmu dan berguru pada beberapa syaikh, sehingga dia tekenal dengan ahli sejarah dan mengarang kitab Tarîkh al-Islâm tebalnya sekitar 17 Jilid sejak munculnya Islam sampai awal abab ke-8. Kemudian ia meringkas kitab "Daul al-Islâm" sebagaimana ia meringkas kitab "Al-Ibr fi Khabari man Abbara" dengan setiap metode yang berbeda-berbeda. Adapun wafat pada hari senin tanggal 3 Dzulqa'dah $748 \mathrm{H}$ dan dikuburkan di Bâb al-Shagîr. ${ }^{13}$ Ibnu katsir juga menyebutkan bahwa ia meninggal pada waktu dzuhur. ${ }^{14}$

Guru-gurunya, Imam al-Dzahabi pernah belajar kepada beberapa ulama yang terkenal dan terkemuka, seperti di Syâm, Hijâj, Mesir dan selainnya pada saat ia berusia 18 tahun. Ia banyak mengarang dalam seluruh macam kitab hadis dan ilmu hadis. Seperti kitab Mu'jam yang memuat 1300 ulama hadis. ${ }^{15}$

Di antara para ulama tersebut adalah Ahmad bin Asâkir kitab Shahîh Muslim, ia belajar darinya al-Muwatha karya Imam Mâlik Riwayat Abi Mush'ab, Amr bin Abdul Mun'im bin al-Qawash, Mu'jam Ibnu Jami' dan Zainab binti Umar bin Kindi. Abi al-Ma'ali Ahmad bin Ishaq al-Abruquhi di Mesir, ia belajar darinya kitab Mu'jam Takhrîh al-Haritsî dan Sirah al-Nabawiyah karya Abi Ishaq, Tabdrif karya Ibnu Hisyam, dan satu Juz karya Ibnu al-Thalayah. Masih di daerah yang sama ia berguru kepada Syarf al-Dimyati. ${ }^{16}$

${ }^{10}$ Muhammad bin Ahmad bin Utsman al-Dzahabi, Tadzkirah al-Huffaz̧ (Beirut: Dar alKutub al-Imiyah, 1998), 4.

${ }^{11}$ Muhammad bin Ahmad bin Utsman al-Dzahabi, Kitab al-Kabair (Beirut: Dar alKutub, 1992), 2.

${ }^{12}$ Ibid.,2.

${ }^{13}$ Ibid., 9.

${ }^{14}$ Muhammad bin Ahmad bin Utsman al-Dzahabi, Al-Muqtani fi al-Sard al-Kuna (AlMamlakah al-Arabiyah al-Su'udiyah: Dar Ihya al-Turats al-Arabiyah, 1408), juz 1, 6.

${ }^{15} \mathrm{Abdul}$ Hai bin Abdul Kabir al-Katani, Fibras al-Faharis wa Itsbat wa Mu'jam al-Ma'ajim wa al-Musyikhat wa al-Musalsalat (Beirut: Dar al-Ghurab al-Islami, 1982), 417.

${ }^{16}$ Muhammad bin Ahmad bin Ali Taqiyuddin Abu Thib al-Makki al-Hasani, Drail alTaqyid fi Ruwat al-Sunan wa al-Asanid (Beirut: Dar al-Kutub al-Ilmiyah, 1990), 53. 
Hajar dan Wazirah, ia belajar darinya kitab al-Bukhâri, dilanjutkan kepada al-Fakhr Ali bin Ahmad bin al-Bukhâri al-Maqdisi satu juz Ibn Hamkan. Muhammad bin Ibrahim bin Tarajum al-Haritsi, ia belajar darinya kitab Jâmi' alTirmidri mulai dari Khat al-Karuhi sampai bab Ja'a fi Khalq al-Nabiyi $S A W$ bi qira'at Quthb al-Din al-Anshari di suatu Majelis terakhir pada tanggal 06 Rabi'ul Akhir tahun 689 H. Darinya pula ia belajar kitab al-Muhadits Syams al-Dîn Muhammad bin Muhammad bin Nabatah, dan kitab Kutub al-Simâ' fi al-Asbl, Naql Syihâbuddin Ahmad bin Abik al-Fariqi. ${ }^{17}$ Syaikh Syams al-Din Muhammad bin Adlan, ia belajar darinya satu juz kitab Muntaqa yang berisi 25 hadis.Abu alKhair Ahmad bin al-Hafizh Shalahuddin Khalil al-'Ala'i bulan Syawwal 44 H.

Ibnu Daqiq al-'Id, dengannya ia bebas mendengarkan pelajaran, hingga suatu ketika Ibnu Daqiq al-'Idi pernah bertanya kepadanya (al-Dzahabi), dari mana kamu? Kemudian beliau menjawab: Saya dari Negeri Syam, lalu beliau bertanya lagi kamu terkenal dengan sebutan apa?, Jawabnya: al-Dzahabi, lalu siapakah Abu Thahir al-Dzahabi?, ia menjawab: ia adalah orang yang ikhlas. Lalu beliau berkata: kamu benar, lalu ia bertanya lagi: siapakah Abu Muhammad alHilali? Ia menjawab: Sufyan bin Uyainah, kemudian ia berkata: kamu benar, lalu ia disuruh menyempurnakan bacaannya setelah ia mengetahui nama-nama tersebut. Dan masih banyak guru-gurunya yang lain.

Selain itu, Guru-guru al-Dzahabi yang disebutkan dalam kitab 'Tażkirah al-Huffäz"secara resmi berjumlah 36 orang-orang. Dalam makalah hanya akan disebutkan 10 guru antara lain: Al-Imam al-Alim al-Muhadits al-Hafidz al-Syahid Abi al-Husain, Ali Ibn Syaikh al-Faqih di Ba'alabak, dia bermulazamah dengannya lebih dari 70 hari, Al-Syaikh al-Imam al-Muhadits Mufidz al-Jama'ah Abu al-Hasan Ali bin Mas'ud bin Nufais al-Mushili, Al-Muhadits al-Imam alMutqin al-Lughawi Shafiyuddin Mahmud bin Abu Bakr al-Amuwi, kemudian alQarafi, al-Shufi, Syarafuddin Ahmad bin Ibrahim al-Siba' al-Fazari al-Syafi'i, Alimuddin Abi Muhammad al-Qasim bin Muhammad bin Yusuf Ibn Al-Hafidz Zakiyuddin al-Barzali, Syamsuddin Abi Abdillah Muhammad bin Abi al-Fath alBa'alabi al-Hanbali, Syamsuddin Muhammad bin Abdurrahman bin Syammah, Qath al-Din Abd al-Karim bin Abd al-Nur bin al-Munir al-Halabi al-Mishri, Syamsuddin Abi al-'Ala'i Mahmud bin Abi Bakr al-Bukhari al-Hanafi, Syamsuddin Muhammad bin Ibrahim bin Ghanaim al-Muhandisi al-Shalihi alHanafi al-Syuruthi ibn al-Muhandis.

Karya-karyanya, Al-Zahabi adalah sebagai penulis yang banyak menulis dalam berbagai macam karya tulis dalam kitab hadis dan karya tulis lainnya yang memberi kontribusi dan manfaat hingga zaman sekarang. Di antara karyakaryanya adalah: kitab Akbbâr Abi Muslim al-Kharasâni, kitab Akbbâr Qudhât alDimasyqi, kitab Al-I'lam bi al-Wâfiyât, kitab Tarîkh al-Islâm, sekitar 10 juz, kitab Al-Tibyân fi ManâqibUtsmân bin Affân, kitab Al-Tajrid fi Asma' al-Sahabah, kitab

${ }^{17}$ Ibid., 55 . 
Tabrîm al-Adbâr, sekitar 2 juz, kitab Tasybi al-Khashîs bi Abl a-Khâmis, kitab Ta'riyah al-Hasanah bi al-Akbirah, kitab Taqwim al-Buldan, kitab Tauqif Abl al-

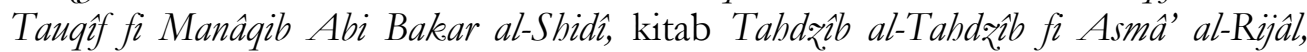
kitab Al-Durrah al-Yatimah fi Sirah Ibni Taimiyyah,yakni Taqiyudin Ahmad, kitab Dau al-Islâm fi al-Tarikh, kitab Al-Rûh wa al-Aujal fi Nabầ al-Masîh al-Dajjâl, kitab Sîrah al-Halâj, kitab Siyar al-Nubala' fi al-Tarikh wa Tarâjim, sekitar 10 juz, kitab Al-Thr fi Khabari man Abbara, kitab Al-Adzâab al-Salsal fi al-Hadìts al-Musalsal, kitab Al-Uluw li Ali al-A'la al-Ghaffâr fi Tdz̧ah al-Akbbâr, kitab Unwan al-Siyar fi Drikeri al-Shabâbah, kitab Fathu al-Mathâlib fi Manâqib Ali bin Abi Thâlib, kitab Qid Nabâruk bi Akbbâr Ibni Mubârak, kitab Al-Kasyîf fi Asmầ al-Rijâl, kitab AlMuqtadbib min Tabd₹̨̂́b al-Kamâl li al-Mizzi, kitab Al-Arys wa Sifatibi, kitab AlKabâir Jaza’an, kitab Al-Witr, kitab Kasyf al-Kurâbah Inda Faqd al-Abibbah, kitab Mâ Ba'da al-Maut, sekitar 1 juz, kitab Al-Mujarrad fî Rijâl al-Kutub al-Sittah alMukbtashar fi Mubadits al-'Ashr, kitab Mukbtashar Silâh al-Mu'min, kitab Mukbtashar Mu'jam al-Syuyûh, kitab Al-Musthalah fì Ikhtishâr al-Muballâ, kitab Musytabih al-Nisbah fì al-Ansâb, kitab Al-Mu'jam al-Shagîr al-Musammâ bi al-Lathîf, Kitab Al-Mu'jam al-Kabîr, kitab Ma'rifat al-Qurầi al-Kibâri 'ala al-Thabaqât wa alAnshâr, kitab Al-Mughni fì Dhu'afầi wa Ba'dhi al-Tsiqât, kitab Al-Muqtani fî Sird alKunâ, kitab Maniyat al-Thâlib li 'Aizat al-Mathâlib, kitab Mìzan al-I'tidâl fî̀ Naqd alRijâl, sekitar 2 juz diterbitkean di India, kitab Ni'am al-Simâr fi Manâqib Umar Radhiyallâbu 'Anbu, kitab Naqdh al-Ja'bah fì Akbbâr Syu'bah, kitab Halâh al-Badr fì Adad Abli Badr. ${ }^{18}$

Kitab Tadzkirah al-Huffarb ini memuat 21 thabaqah yang terdiri dari thabaqah pertama sampai tabaqah terakhir, dimulai dengan muqadimah dari pengarang dalam kitab tersebut.

Secara komprehensif kitab Tadzkiratal-Huffazh ini terdiri dari 4 juz, 21 Thabaqah (tingkatan) yang berisi 1.111 nama-nama dan gelar perawi hadis dari mulai dari Abu Bakar al-Shiddîq sampai kepada perawi terakhir Jamaluddîn Abu al-Hajâj Yusuf bin Zakki Abdurrahman bin Yusuf al-Qadha’i al-Kalbi alDamsyiqi al-Syâfi'i. Selain itu, kitab tersebut menyebutkan beberapa hadis yang terkait dengan pujian terhadap perawi hadis.

Sebagai contoh hadis tentang berkata benar dan larangan berbuat bohong sebagai berikut:

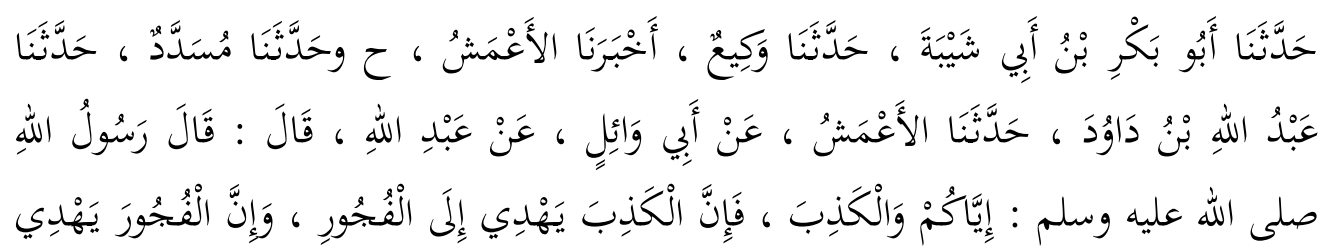

${ }^{18}$ Muhammad bin Ahmad bin Utsman al-Dzahabi, Tad₹kirat al-Huffąh...., 4. 


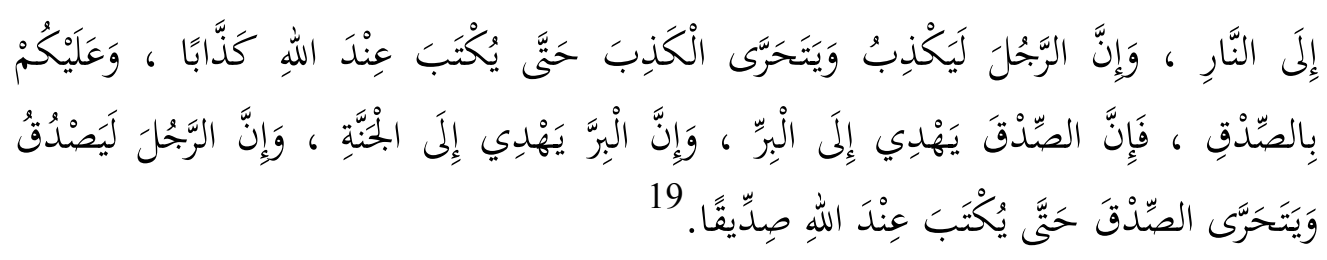

Hadis ini disebutkan secara terpisah-pisah dalam kitab "Taغंkiratul huffäz" terkait dengan pernyataan sahabat Yunus dari al-Zuhri yang pernah mendengar Abu Bakr berkata seperti ini. Selain itu, terkait dengan lafadz al-Shadiq yang artinya benar dan tidak mungkin berkata bohong. Inilah pujian yang disampaikan oleh para ulama hadis dengan kejujuran Abu Bakr, sehingga diberi gelar al-Shidiq.

Kitab hadis yang dikutip Imam al-Dzahabi adalah kitab al-Bukhari, Muslim, Ibnu Majah dan Abu Dawud dan Muttafaq 'Alaih. Namun tidak semua hadis tersebut ada dalam semua thabaqah, hanya beberapa thabaqah.

Jadi kitab ini hanya memuat thabaqah para hafidz hadis, pengarangnya lebih dahulu menyebutkan biografi para hafidz hadis. kemudian orang-orang yang mereka nilai tsigah atau dhaîf sebagai disebutkan dalam muqaddimahnya. Kitab ini juga merupakan catatan tentang nama para penilai keadilan perawi hadis, dan orang-orang mereka dinilai tsiqah, dhaîf, dan shabîh. Selain itu, pengarang juga menyebutkan para perawi hadis dan imam ahli Jarb wa Ta'dîl yang masyhur, mulai thabaqah sahabat sampai guru-guru pengarang kitab ini (alDzahabi) yang dibagi menjadi 21 thabaqah. Sehingga biografinya dalam kitab ini mencapai $1.111 .^{20}$

Kitab ini sangat berguna untuk mengetahui para perawi hadis yang masyhur pada setiap thabaqah mulai masa sahabat sampai al-Dzahabi yaitu sekitar pertengahan abad kedelapan.

Untuk menyempurnakan kitab ini, tiga ulama besar memberikan catatan lampiran tambahan, yaitu al-Husaini $(765 \mathrm{H})$, Ibnu Fahd al-Makki $(871 \mathrm{H})$, dan Jalaluddin al-Suyuti $(911 \mathrm{H})$. Selain tiga catatan lampiran tersebut, dalam kitab ini terhimpun biografi perawi hadis dan hafidznya sejak abad pertama sampai awal abad kesepuluh. ${ }^{21}$

Pendapat para ulama, ImamTajuddin al-Subki mengatakan dalam bukunya Thabaqât al-Syâfi'iyah al-Kubrâ" mengatakan bahwa al-Dzahabi adalah gurunya Abu Abdillah, ia seorang yang cerdas dan ilmunya tidak ada yang

\footnotetext{
${ }^{19} \mathrm{Abu}$ Dawud Sulaiman bin al-Asy'ats al-Sijistani, Sunan Abi Dawnd (Riyadh: Bait alAfakr al-Dawliyah, t.t), juz 4, 454.

20 Mahmud Tahhan, Metode Takbrij dan Penelitian Sanad Hadis, terj. Ridwan Nasir (Surabaya: Bina Ilmu Offset, 1995), 112.

${ }^{21}$ Kitab ini telah dicetak berulang kali, terakhir diterbitkan oleh Daru Ihya Turas alArabi, Beirut, dengan catatan tambahan tiga ulama tersebut.
} 
menandinginya, dan ia menjadi rujukan ketika terjadi suatu permasalahan. Penghulu manusia dalam hafalan, pemimpin Imam Madzhab pada masanya, baik secara maknawi maupun lafž̉i. Dia ahli dalam bidang al-Jarh wa al-Ta'dîl dan tokoh dalam semua jalan, seakan-akan umat manusia berdiri di satu tangga. Sedangkan beliau melihat mereka dan memberitahu mereka tentang orang yang hadir kepada mereka. Suatu ketika ia pernah kelelahan karena selalu membaca dan menulis yang tiada henti. ${ }^{22}$

Ibnu Syakir al-Katabi berpendapat dalam kitab Fuat al-Wafayât menyebabkan bahwa al-Dzahabi adalah orang yang kuat hafalannya, sehingga tidak ada bagian satu bukupun yang tidak pernah dibaca, seorang ahli hadis dan perawi hadis, dan selalu memperhatikan kecacatan suatu hadis, memperkenalkan kepada orang-orang tentang biografi perawi hadis, menjelaskan kesamaran para perawi dalam kitab sejarah mereka. Kemudian ia terkenal banyak mengarang kitab-kitab (bukan ringkasan) dan kitab-kitab ringkasan. Syamsuddin Abu alMahâsin Muhammad bin Ali al-Husaini wafat 765 H. Ia menilai bahwa alDzahabi termasuk bagian dari Ahli hadis yang harus dijadikan panutan dan diikuti oleh para penghafal dan para ahli qira'ât, seorang muhadits dari Syam, pakar sejarah dan ahli hikmah. ${ }^{23}$

Jika dibandingkan kitab Taغ̌kirah al-Huffä̌̆h dengan kitab Thabaqâh alHuffâz̆ karya al-Suyûthi. Maka menurut Sa'a bin Abdullah Âli Humaid, beliau mengatakan, kitab Thabaqâh al-Huffâz̧ karya al-Suyûthi hanya menyebutkan dan mensifati para penghafal hadis yang sudah diketahui kekuatan hafalannya yang disusun berdasarkan thabaqah. Sedangkan kitab Tadækirah al-Huffąh tidak menyebutkan para penghafal hadis yang diketahui berdasarkan tingkatan hafalannya, akan tetapi hanya menyebutkan dan membicarakan tentang para perawi yang dinilai jarh dan adil dan hadis-hadis yang dinilai shabîh dan dhaîf. Menurutnya perkara ini wajib diketahui agar tidak menimbulkan prasangka kepada al-Dzahabi yang menyebutkan dalam kitabnya tersebut, tentang para penghafal hadis yang dijadikan sebagai bujjah. Sebagai contoh al-Dzahabi menyebutkan Ibnu Lahi'ah dalam kitabnya, padahal Ibnu Lahi'ah terkenal sebagai orang yang tidak hafal hadis. Demikian juga Abu Hanifah, dia dikatakan sebagai penghafal hadis, padahal dia lemah hafalan hadisnya. ${ }^{24}$

Menurut hemat penulis, ini adalah kritik cukup mendalam yang disampaikan seorang ulama kepada al-Dzahabi yang mengarang kitab tersebut. sekalipun al-Dzahabi seorang yang ahli dalam bidang kritik sanad dan matan hadis yang terkenal dengan Jarh wa Ta'dill-nya, dan penilai terhadap hadis shahîh

\footnotetext{
22Tajuddin bin Ali bin Abdillah al-Kafi al-Subki, Tabaqatu al-Syafi'i al-Kubra (Tp.,: Dar Ihya al-Kutub al-Arabiyah), juz 9, 103.

${ }^{23}$ Muhammad bin Ahmad bin Utsman al-Dzahabi, Al-Muqtani fi al-Sard al-Kuna, 6.

${ }^{24} \mathrm{~S} a$ 'ad bin Abdillah Ali Humaid, Fatâwâ Haditsiyah (Riyadh: Dar Ulum al-Sunnah, 1999), juz 1,24 .
} 
dan dhaîf. Sehingga tidak mungkin al-Dzahabi menyebutkan biografi para perawi hadis yang benar-benar hafidz dalam bidang hadis.

Namun demikian, pendapat lain mengatakan bahwa al-Dzahabi menyampaikan dalam kitab Tad₹kirah al-Huffazh tentang para penghafal hadis sesuai dengan tingkat hafalan. Dalam pendahuluannya ia mengatakan bahwa kitab tersebut menyebutkan orang-orang yang adil, yang mengetahui kenabian (Muhammad) dan orang yang merujuk (mengembalikan suatu masalah) kepada ijtihad dalam ketsiqahan, kedhaifan, dan keshahihannya. ${ }^{25}$

Sistematika kitab Tażkirah al-Huffäz tersebut disusun berdasarkan tingkatan kecerdasan dan hafalan para ulama hadis dalam setiap thabaqah. Oleh karena itu, ia meletakan Abu Bakar pada thabaqah pertama dan dilanjutkan dengan Umar bin Khathâb, Utsmân bin Affân dan Ali bin Abi Thâlib dan seterusnya. Empat orang ini disebutkan dalam kitab Sirah Nabawiyah dengan gelar Khulafầur al-Râsyidîn.

Dalam kata pengantar kitab Taそ̌kirah al-Huffäz, al-Zahabi membagi laqablaqab berdasarkan kemampuan para perawi hadis, diantaranya ada yang disebut dengan Musnid, al-Mubadits, al-Hafidr, al-Hujjah,al-Hakim, dan Amir al-Mukminin fi al-Hadis. ${ }^{26}$ Menurut hemat penulis, sistematika penyusunan kitab tersebut disusun berdasarkan thabaqah yang ada, juz pertama dari thabaqah pertama sampai thabaqah yang ketujuh angkanya berurutan. Pada juz kedua dari thabaqah kedelapan sampai kesepuluh dan juz-juz selanjutnya angkanya tidak berurutan.

Sistematika kitab Taغ̌kiratul buffä̌b bisa diklasifikasikan berdasarkan juz. sebagai berikut:

Juz pertama dibagi menjadi tujuh thabaqah yang terdiri dari nama-nama perawi hadis, di antaranya: thabaqab pertama terdiri dari 23 perawi hadis, mulai nomor 1-23, thabaqah kedua terdiri dari 42 perawi hadis, nomor 24-65, thabaqah ketiga terdiri dari 30 perawi hadis, nomor 66-95, thabaqah keempat terdiri dari 58 perawi hadis, nomor 96-153, thabaqab kelima terdiri dari 78 perawi hadis, nomor

\footnotetext{
${ }^{25}$ Aiman Mahmud Mahdi, Al-Jarh wa al-Ta'dîl Bain al-Nadzariyah wa al-Tathbîq (CD Maktabah al-Syamilah, versi 3.28), juz 1,16.

26 Musnid adalah orang yang meriwayatkan sebuah hadis dari rasulullah dengan sanadnya, apakah dia memiliki keilmuan dibidnag hadis ataupun hanya meriwayatkan sebuah hadis, sedangkan al-Muhadits adalah orang yang menyibukan dirinya untuk mengetahui ilmu hadis riwayah dan dirayah dan mempelajari atau meneliti banyak riwayah-riwayah dan keadaan perawi-perawinya. Lihat Ali bin Nayif al-Syuhud, al-Mufashal fi Ulüm al-Hadits, juz 1,13. Sedangkan al-Hafidz adalah orang yang meriwayatkan seratus ribu hadis sanad dan matanya menurut pendapat para ulama hadis. al-Hujjah adalah orang yang mumpuni dalam bidang ilmu hadis, sehingga dia dapat menguasai dan menghafal tiga ratus ribu hadis berdasarkan pendapat para ulama hadis. lihat Hafidz Tsanaullah al-Zahidi, al-Fushul fi Musthalah al-Hadits al-Rasul, juz 1, 6. Al-Hakim adalah orang yang diberikan kemudahan untuk menguasai ilmu hadis. Ini adalah menurut sebagian ulama ahli ilmu. Lihat Mahmud Thahan, Taisir Mushthalah al-Hadits,16.
} 
154-231, thabaqah keenam terdiri dari 81 perawi hadis, nomor 232-312, thabaqah ketujuh terdiri dari 106 perawi hadis, nomor 313-418.

Juz kedua dibagi menjadi tiga thabaqah sebagai lanjutan dari juz pertama yang nama-nama seorang perawi hadis di antaranya: thabaqab kedelapan terdiri dari 130 perawi hadis, nomor 1-130, thabaqah kesembilan terdiri dari 106 perawi hadis, nomor 1-160, thabaqab kesepuluh terdiri dari 117 perawi hadis, nomor 1117.

Juz ketiga dibagi menjadi empat thabaqah sebagai lanjutan dari juzkedua yang nama-nama seorang perawi hadis, di antaranya: thabaqah kesebelas terdiri dari 77 perawi hadis, nomor 1-77, thabaqah keduabelas terdiri dari 79 perawi hadis, nomor 1-79, thabaqah ketigabelas terdiri dari 9 perawi hadis, nomor 1-9, thabaqah keempatbelas terdiri dari 31 perawi hadis, nomor 1-31.

Ju₹ keempat dibagi menjadi tujuh thabaqah sebagai lanjutan dari juz ketiga yang nama-nama seorang perawi hadis, di antaranya: thabaqah kelimabelas terdiri dari 46 perawi hadis, nomor 1-46, thabaqah keenambelas terdiri dari 18 perawi hadis, nomor 1-18, thabaqab ketujuhbelas terdiri dari 25 perawi hadis, nomor 1 25, thabaqah kedelapanbelas terdiri dari 26 perawi hadis, nomor 1-26, thabaqah kesembilanbelas terdiri dari 12 perawi hadis, nomor 1-12, thabaqah keduapuluh terdiri dari 10 perawi hadis, nomor 1-10, dan thabaqah keduapuluh satu terdiri dari 7 perawi hadis, nomor 1-7.

Kualitas Hadis, hadis-hadis yang diteliti mulai dari thabaqah pertama sampai thabaqah keempat. Berdasarkan penelitian penulis, dengan menggunakan Mausu'ah dan Maktabah al-Syamilah, dalam kitab Tadrkirah al-Huffärb ditemukan hadis-hadis yang terdapat dalam empat thabaqah. Hadis yang bernilai shabîh yaitu hadis yang diriwayatkan oleh Al-Bukhari dalam thabaqah pertama, kedua dan keempat, Muslim dalam thabaqah keempat, dan Ibnu Majah dalam thabaqah pertama. Sedangkan hadis yang dinilai hasan diriwayatkan oleh Ibnu Majah dalam thabaqah keempat dan Abu Dawud dalam thabaqah keempat, dan hasan gharib diriwayatkan oleh al-Tirmidzi dalam thabaqah kedua. ${ }^{27}$

Jika dicermati hadis-hadis dalam kitab Taغkirah al-Huffä̧h boleh dikatakan kualitasnya sangat beragam, walaupun belum secara keseluruhan penulis melakukan sebuah penelitian. Namun tidak menutup kemungkinan hadis-hadis yang diangkat bisa sampai pada derajat dhaif dan manquf, apalagi menyangkut tentang keutamaan sahabat yang menghafal sebuah hadis dari Rasulullah. Adapun hadis-hadisnya yang dikutip sebagai berikut:

${ }^{27}$ Penilaian hadis ini didasarkan pada penelusuran penulis dalam CD Mausu'ah, $\mathrm{Al}$ Hadis al-Syarif, Global Islamic Software Company, 2000, dan CD Maktabah al-Syamilah Versi 3.28. dengan melihat pendapat ulama hadis seperti al-Tirimidzi dalam kitab sunannya dan Syaikh Nashiruddin al-Bani. 
1. Șaḥị̣ al-Bukhāri no.106 (Thabaqah ke-1)

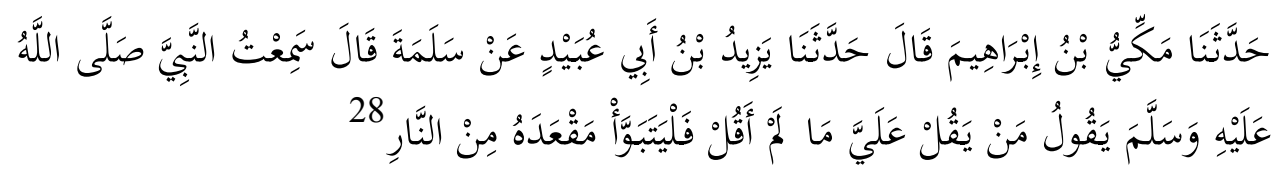

2. Sunan Ibnu Mājah no.40 (Thabaqah ke-1)

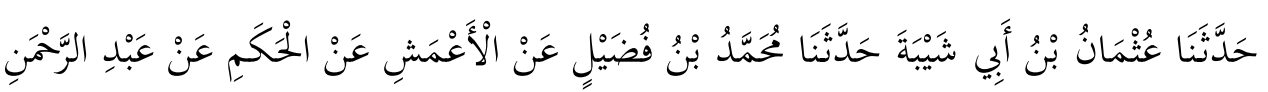

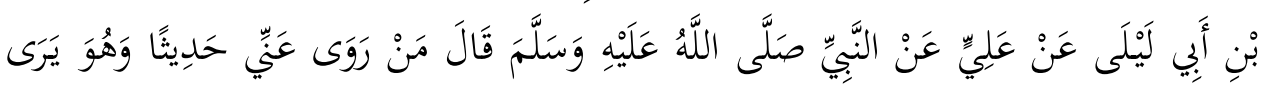

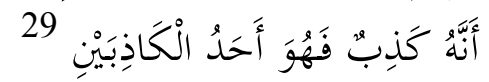

3. Sunan Al-Tirmizī no. 3619 (Thabaqah ke-2)

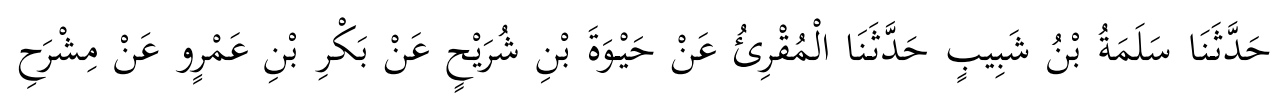

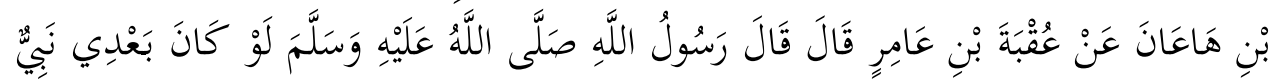

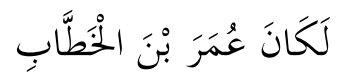

4. Sunan Al-Tirmizī, no. 3646. (Thabaqah ke-4)

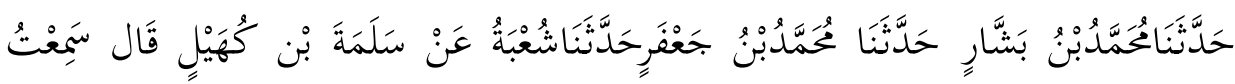

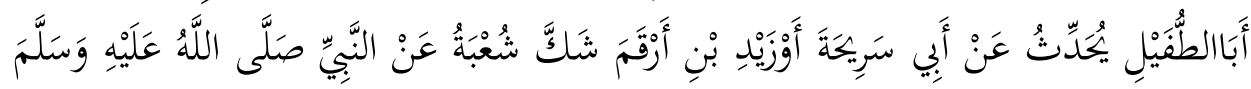

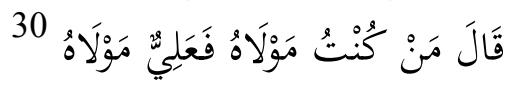

5. Sunan Ibnu Mājah, no. 118. (Thabaqah ke-4)

حدثنا علي بن محمد حدثنا أبو معاوية حدثنا موسى بن مسلم عن ابن سابط وهو عبد الرحمن عن سعد بن أبي وقاص: قال قدم معاوية في بعض حجاته فدخل عليه سعد فذكروا عليا فنال منه فغضب سعد وقال تقول هذا لرجل سمعت رسول الله صلى الله عليه وسلم

${ }^{28}$ Muhammad bin Isma'il bin Ibrahim bin al-Mughirah al-Bukhari, Shabih al-Bukbari (Beirut: Dar al-Thuq al-Najah, 1422), juz 1, 33.

${ }^{29} \mathrm{Abu}$ Abdillah Muhammad bin Yazid al-Qazwini, Sunan Ibni Majab (Tp.,: Dar Ihya alTurats, t.t), juz 1, 14.

${ }^{30}$ Muhammad bin Isa bin Saurah al-Tirmidzi, Sunan al-Tirmidzi (Riyadh: Maktabah alMa'arif, t.t), juz 5, 633. 


$$
\text { يقول من كنت مولاه فعلي مولاه وسمعته يقول أنت مني بمنزلة هارون من موسى إلا أنه لا }
$$

6. Sahīh Al-Bukhāri, no. 3699 (Thabaqah ke-4)

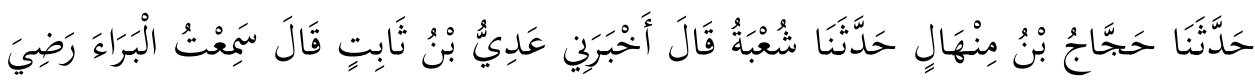

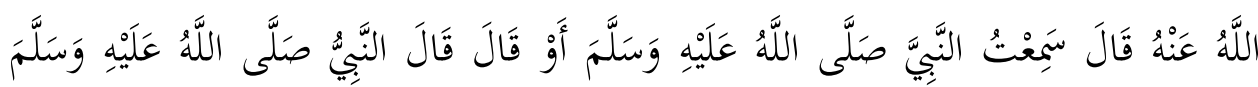

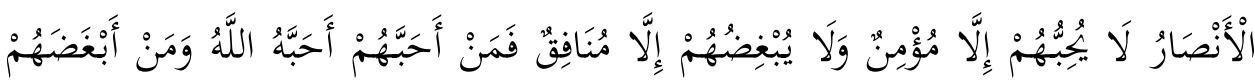

32 أبَْغَضَهَهُ اللَّهُ

7. Sahîh Muslim, no.110 (Thabaqah ke-4)

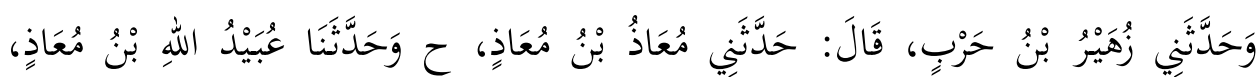

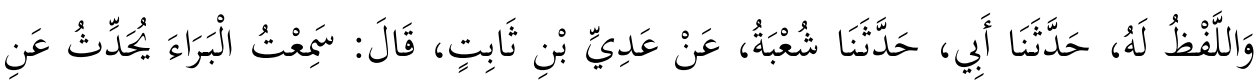

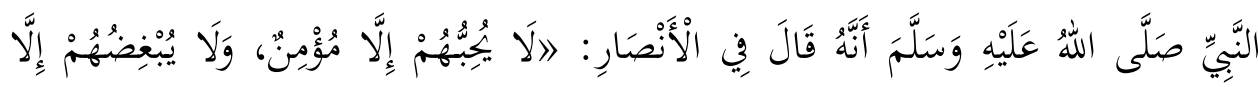

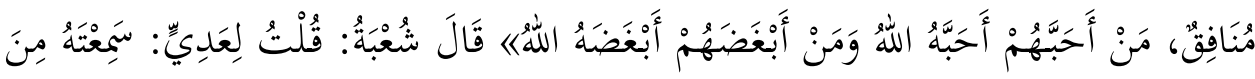

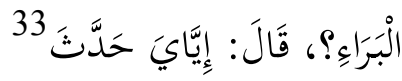

8. Sunan Abu Dâud, no. 1300 (Thabaqah ke-4)

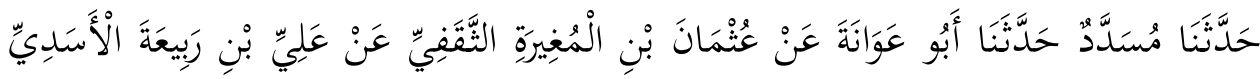

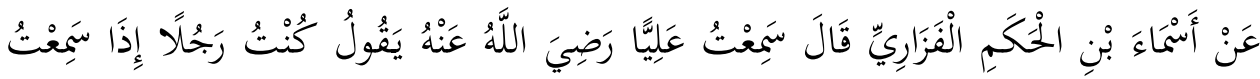

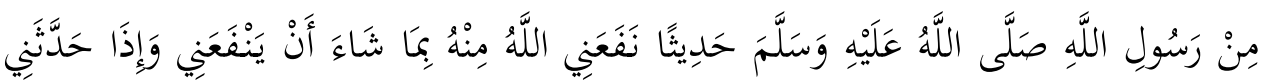

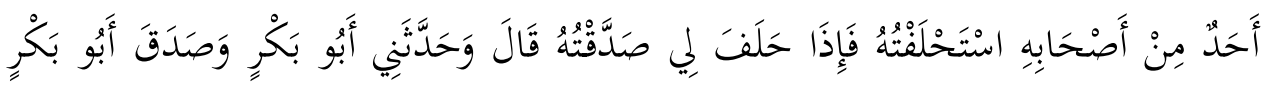

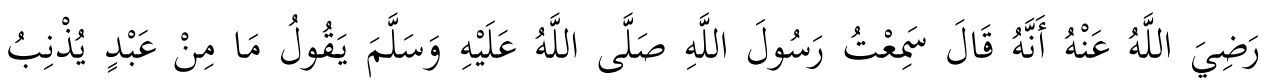

${ }^{31} \mathrm{Abu}$ Abdillah Muhammad bin Yazid al-Qazwini, Sunan Ibni Majah, juz 1, 45.

${ }^{32}$ Muhammad bin Isma'il bin Ibrahim bin al-MughirahAl-Bukhari, Shabih al-Bukhari, juz 5, 32 .

${ }^{33} \mathrm{Abu}$ Nuaim, Al-Musnad al-Mustakhraj 'ala al-Imam Muslim Al-Asbahaniy (Riyadh: Bait al-Afkar al-Dawliyah, 1998), juz 1, 85. 


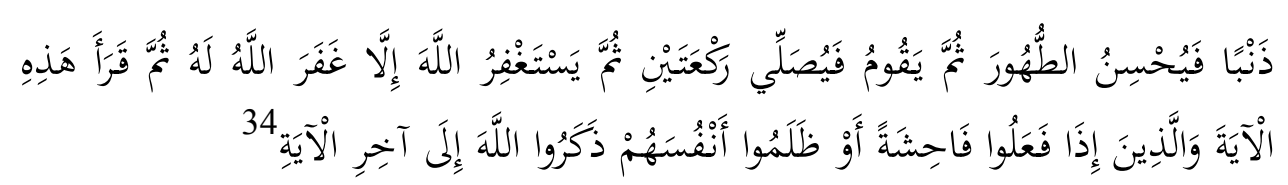

\section{Kitāb al-Rijāl versi Syiah}

Kitāb al-Rijäl versi Syiah ${ }^{35}$ ini merupakan sebuah karya dari Taqiyyuddin al-Hasan bin Ali bin Dawud al-Hulli Qudus Sirruhu, ia lahir pada tahun 647 Hijriyyah dan wafat pada 707.

Nama lengkapnya adalah Al-'Allamah Shadid bin Muhammad Bahrul Ulum Syaikh Taqiyuddin Abu Muhamad al-Hasan bin Ali bin Dawud yang dikenal dalam kitab-kitab mu'jam al-Rijal karya al-Hasan bin Dawud ini merupakan sebuah nama yang dinisbatkan kepada kakeknya. Ia adalah seorang yang alim, mulia, utama, shalih, dan santun, ahli fiqh dan ahli hadis.

Guru-gurunya adalah Jamaluddin Ahmad bin Thawus, Abdul Karim ibn Sayyid Ahmab bin Thawus, Najmuddin Abi al-Qasim Jakfar bin Husain bin Yahya bin Said al-Hulli, dan Mufiduddin Muhammad bin Ali bin Muhammad bin Jahim al-Asadi.

Murid-murinya adalah Radhiyuddin Abu Hasan Ali bin Ahmad bin Yahya al-Mazidi al-Hulli, Zainuddin Ali bin Ahmad bin Tharad al-Mutharabadi, dan Sayyid Tajuddin Abu Abdillah bin Muhammad ibnu Sayyid Jalaluddin alHulli.

Pendapat para ulama mengenai pengarang yakni Dawud al-Hulli: alKhawanisari mengatakan dalam Kitab Raudhah al-Janah bahwa Syahid meriwayatkan melalui Ali bin Ahmad al-Mazidi dan Ibnu Maiyah dan semisalnya, al-Hurri al-Amili menyebutkan dalam kitab Amal al-Amal bahwa al-Hulli adalah seorang yang alim, utama, mulia, shalih, seorang pentahqiq dan termasuk dari Najmuddin al-Hulli yang diriwayatkan oleh Syahid dari Ibnu Maiyyah. Husain bin Abdusshamad al-Amili menilai bahwa al-Hulli adalah seorang yang faqih dan beradab (berakhlak mulia), ahli nahwu, seorang penyair dan seorang raja yang alim. Syaikh Ali bin Abdul Ali al-Karki mengatakan bahwa ia adalah seorang Imam penguasa yang santun dan komunikatif, seorang muhaddis, dan ahli fiqh. Mushtafa al-Tafrisi mengatakan bahwa ia juga seorang mujtahid yang mulia, imam besar, dan faqih di kalangan ahlul bait.

Karya-karyanya adalah Kitāb al-Rijäl, Tahshilul Manāfi', Riyādh al-Ulama', Idhah al-Manäfi, Hasanah al-Uslüb dan Jayyidah al-Ną̧am.

\footnotetext{
${ }^{34} \mathrm{Abu}$ Dawud Sulaiman bin al-Asy'ats, Sunan Abi Daudal-Sijistani (Riyadh: Bait al-Afkar al-Dawliyah, t.t), juz 1, 561 .

35 Taqiyyuddin al-Hasan bin Ali bin Dawud al-Hulli, Kitäb al-Rijäl (CD Maktabah Syamilah versi 3.48).
} 
Sistematika Kitāb al-Rijäl disusun berdasarkan huruf, yaitu menyebutkan nama-nama periwayat, nama-nama ayah, dan nama-nama kakek serta seluruh yang ada di dalamnya dan disusun dengan tertib dan tahdzib sebagaimana kitab versi Sunni Ibnu Hajar al-Asqalani yakni kitab Tahdzib al-Tahdib dan Tahdzib alKamal. Selain itu, referensinya disebutkan kitab karya Syaikh, al-Kasyi, Najasyi dan beberapa Kitāb al-Rijäl karya ulama lainnya. Dalam kitab tersebut, disebutkan beberapa bab dan pada setiap bab ada satu atau dua huruf yang berpatokan pada nama-nama periwayat, namun sedikit sekali mengungkap ulama Mutaakhirin.

Menurut kritikus hadis, Kitāb al-Rijäl ini memang tersusun dengan baik namun di dalamnya terdapat banyak kesalahan. Abu al-Huda al-Kalbasi dan alAsfahani menghitung kesalahan kitab tersebut dalam 92 halaman sebagaimana disebutkan dalam kitab karyanya Samā' al-Maqäl fi Tahqiq 'ilmi al-Rijäl. Kitäb alRijäl karya al-Hulli ini disusun seperti kitab al-Mu'jam dan merupakan kitab yang dinukil dari Ijaz al-Maqal fi Ma'rifah al-Rijal karya Syaikh Farjuddin bin Muhammad bin Duruwis bin Husain bin Hammad bin Akbar.

Selanjutnya, ia mengelompokan para periwayat hadis dalam beberapa pasal, yaitu: Pasal pertama, membahas periwayat yang manquf yang disusun menurut hafalan secara ringkas. Pasal kedua, membahas susunan para periwayat yang tertib dan berurutan. Pasal ketiga, susunan kelompok periwayat yang termasuk Syiah Zaidiyah. Pasal keempat, kelompok ulama yang tersusun secara umum. Pasal kelima, kelompok para periwayat yang suka melakukan penggelapan. Pasal keenam, kelompok orang yang lemah. Pasal ketujuh, menyebutkan kelompok periwayat yang mudhtharib. Pasal kedelapan, kitab ini menyembutkan kelompok orang yang munkar. Pasal kesembilan, menjelaskan motivasi orang yang merusak mazhabnya. Pasal kesepuluh, kelompok orang yang maudhu'. Pasal kesebelas, kelompok orang-lemah atau dha'if. Pasal keduabelas, kelompok yang dilaknat. Pasal ketigabelas, kelompok orang tidak bermasalah. Pasal keempatbelas, kelompok orang yang majhul (tidak diketahui identitasnya).

\section{Persamaan dan Perbedaan Kitab Tażkirah al-Huffāz versi Sunni dan Kitāb al-Rijāl versi Syiah.}

Untuk mengetahui persamaan dan perbedaan dua kitab tersebut, penulis melakukan studi analisis terhadap kitab Taqkirah al-Huffaz karya az-Zahabi di atas, kemudian dikomparatifkan dengan Kitäbur Rijäl Versi Syìah karya Taqiyyuddin al-Hasan bin Ali bin Daud al-Hulli3 ${ }^{36}$. Point penting yang akan dianalisis adalah aspek sistematika, isi kitab dan hadis-hadis yang dijadikan bahan sanjungan periwayat hadis.

\footnotetext{
${ }^{36}$ Taqiyyuddin al-Hasan bin Ali bin Daud al-Hulli, Kitab al-Rijal (CD Maktabah asySyamilah Versi 3,28), juz 1, 3.
} 


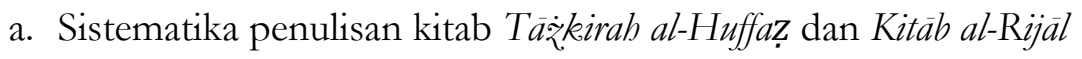

Persamaan sistematika dua kitab tersebut adalah keduanya sama-sama membahas para periwayat hadis dengan sistematika seperti kitab kamus Mu’jam namun tidak disusun berdasarkan huruf abjad yang dikarang oleh para ulama salaf maupun khalaf.

Perbedaaan adalah sistematika penulisan Tadzkirah al-Huffazh disusun berdasarkan juz dan derivasinya. Satu juz dengan yang lain berhubungan karena disusun berdasarkan tingkat kredibilitas seorang periwayat, seperti halnya Abu Bakar dicantumkan dalam tingkat pertama, dikarenakan Abu Bakar seorang sosok manusia yang pertama kali masuk Islam dan pertama kali membenarkan peristiwa isra' mi'raj dan khalifah Rasyidin pertama setelah Nabi meninggal dunia. ${ }^{37}$

Sedangkan Kitāb al-Rijal karya al-Hulli disusun berdasarkan bab, seperti bab pertama menjelaskan tentang biografi seorang penulis, dan disusun dengan tertib berdasarkan huruf hijaiyah dari mulai huruf A sampai huruf Ya, misalnya huruf Aa (أ) memiliki 224 nama periwayat, kemudian dilanjutkan pada huruf Ba (ب) dengan nomor urut 225, dan begitu seterusnya sampai huruf dan nomor urut terakhir hingga huruf terakhir.

Selain itu, pengarang Kitāb al-Rijal karya al-Hulli mengklasifikasikan periwayat hadis menjadi beberapa pasal, pada setiap pasal masing-masing periwayat disebutkan tentang kualitas periwayat hadis. Misalnya, pasal pertama membahas orang-orang yang mauquf sampai pasal terakhir yakni pasal keempatbelas yang membahas tentang orang-orang yang majbul.

b. Isi Kitab Tadqkirat al-Huffäzh dan Kitāb al-Rijäl

Tampaknya pengarang kitab Taغ̇kirat al-Huffä̧̧ ingin memproklamirkan tentang kehebatan umat Islam, khususnya para buffazh yang mumpuni dalam bidang hadis. Dia berhasil mengumpulkan para periwayat dalam satu kitab yakni Taqkirat al-Huffarh. Disebutkan, mereka para sahabat bisa menghafal ribuan hadis dari Rasulullah SAW, seperti Abu Hurairah bisa menghafal 5.374 hadis menurut Ibnu al-Jauzi dalam kitab Talqib Fubumi abl Asar, sedang menurut alKirmani 5.364 hadis, dan dalam Musnad Imam Abmad bin Hanbal sekitar 3.848 hadis. Kemudian disusul oleh Abdullah bin Umar yang berhasil menghafal 2.630 hadis, Anas bin Malik 2.276 hadis, al-Kirmani menyebutkan 2.236 hadis, Aisyah seorang Istri Rasulullah yang tergolong masih gadis di antara istri-istrinya yang lain, ia dapat menghafal 2.210 hadis, Abdullah bin Abbas 1.660 hadis, Jabir bin Abdillah 1.540 hadis, dan Abu Sa'id al-Hudri 1.170 hadis. ${ }^{38}$

Apabila diperhatikan secara seksama, maka tidak ada yang melebihi kapasitas hafalan hadis mereka dari Rasulullah. Mereka adalah generasi terbaik

\footnotetext{
${ }^{37}$ Samsul Munir Amin, Sejarah Peradaban Islam (Jakarta: Amzah, 2010), 93.

${ }^{38}$ TM. Hasbi ash-Shiddieqy, Sejarah dan Pengantar Ilmu Hadis (Semarang: Pustaka Rizki Putra, 2010), 47-48.
} 
setelah Nabi meninggal dunia, sebagaimana disebutkan dalam sebuah hadis, yaitu:

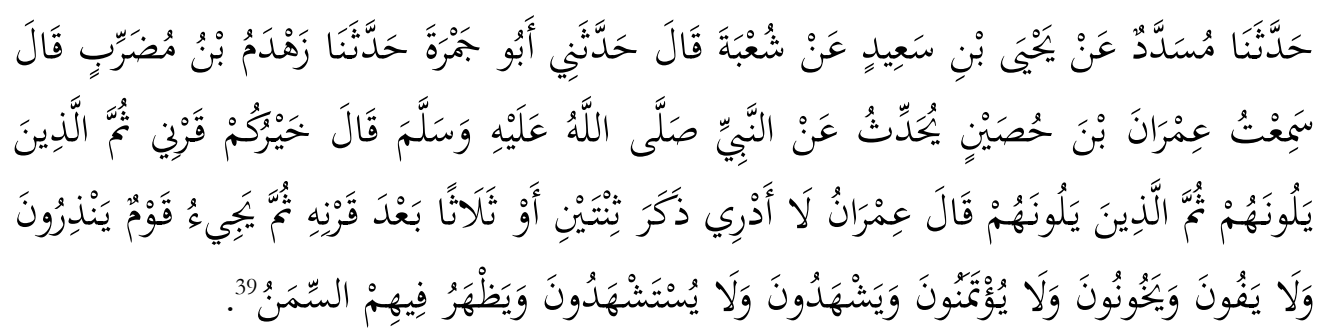

"Telah menceritakan kepada kami Musaddad dari Yabya bin Sa'id dari Syu'bah ia berkata, telah menceritkan kepada-ku Abu Jamrah, telah menceritakan kepada kami Zabdam bin Mudarib, ia berkata, Aku mendengar Imran bin Husain menceritakan dari Nabi SAW bersabda: "Sebaik-baiknya kalian adalab generasiku kemudian orang yang berikutnya dan orang berikutnya, Imran berkata, Aku tidak mengetabui penyebutan dua atau tiga orang setelah generasinya, kemudian datang suatu kaum memberi peringatan dan tidak pernah rusak dan tidak berkbianat, dan tidak diamanabi, mereka bersaksi dan tidak pernah diminta untuk menjadi saksi dan tampak pada mereka gemuk",

Apabila dibandingkan dengan Kitab al-Rijal versi Syi'ah. Kitab ini berisi tentang pujian dan celaan terhadap seorang periwayat hadis, yang dikritik oleh ulama hadis Syi'ah yang terkenal yakni at-Tusi dan an-Najasyi. Para periwayat hadis mendapatkan pujian dengan kata-kata tsiqah, namun ada juga mencela dengan ghalat (salah).

Dalam kitab ini, ditemukan beberapa kesalahan sebagaimana dikatakan oleh Syaikh al-Alamah al-Muhaqiq Abul Hadi al-Kalbasi al-Asfahani, bahwa kitab tersebut mengandung 92 kesalahan sebagaimana disebutkan dalam kitab Sima' al-Qaul dalam mentahqiq Ilmu ar-Rijäl, dicetak di Iran pada tahun $1372 \mathrm{H}$. Sekarang kitab ini menjadi rujukan kaum Syiah. Namun pengarang tidak mempermasalahkan kesalahan tersebut. Dalam hal ini pengarang berhasil membuktikan dan menjelaskan tingkatan para periwayat tertinggi sampai terendah sesuai derajat kesiqahannya dan kemampuannya. Biografi para periwayat ditulis sesuai dengan kapasitas keilmuannya namun tidak utuh. Hal ini tampak terlihat ketika pengarang mencantumkan biografi periwayat tidak secara lengkap, bahkan tidak dicantumkan sama sekali.

Selanjutnya, pengarang mencantumkan empat belas klasifikasi periwayat yang dinilai manquf, maudbu', lemah atau dha'if, mudhtharib dan majhul. Tampak pengarang sangat ketat dalam mengumpulkan periwayat hadis sekaligus mengkritik dan menilai jarb (negatif) akan periwayat yang memang terbukti melakukan kecurangan dalam meriwayatkan sebuah hadis yang bersumber dari

${ }^{39}$ Muhammad bin Isma'il bin Ibrahim bin al-Mughirah al-Bukhari, Sabih al-Bukhari (CD. Maktabah asy-Syamilah, Versi 3.48), Vol. 8, 141. 
imam mereka, tetapi di sisi yang lain pengarang juga mencantumkan golongan periwayat hadis yang dinilai ta'dil (positif).

c. Kualitas Hadis-hadis

Hadis-hadis dalam kitab Tarkirah al-Huffarh mempunyai kualitas hadis yang cukup baik, namun tidak menutup kemungkinan memiliki kualitas yang beragam, seperti sahih, hasan dan dhaif bahkan mauquf karena merupakan perkataan sahabat, misalnya:

حماد بن سلمة عن أبي الزبير عنه قال: استغفر لي رسول الله صلى الله عليه وآله وسلم ليلة البعير خمسا وعشرين مرة، وقيل انه شهد بدرا.

"Hamad bin Salamah meriwayatkan dari Abi Zubair berkata:"Rasulullah SAW memintakekan ampun kepada-ku pada malam al-Ba'ir selama 25 kali. Dikatakan ia mengikuti perang Badar'.

Banyak ungkapan yang lain yang memuji para periwayat hadis. ungkapan tersebut disampaikan para ulama yang menilai baik. Pengarang mencantumkan beberapa orang periwayat baik dari kalangan sahabat, tabi'in, dan tabi'u al-Tabiin. Secara umum penulis memandang bahwa hadis-hadis yang disebutkan dalam kitab Tazkiratul huffaz tidak banyak karena pengarang memfokukan kajiannya pada tabaqab sanad.

Kualitas hadis yang disebutkan secara langsung diterima para sahabat dari Nabi yang tercantum dalam kitab tersebut adalah:

$$
\begin{aligned}
& \text { أخبرنا أحمد بن سلامة في كتابه وحدثني عنه الحافظ البحود أبوالحجاج الكلبي أن مسعود بن } \\
& \text { أبي منصور أنبأهم قال: أنا أبو علي أنا أبو نعيم الحافظ ثنا ابن خلاد ثنا محمد بن عثمان بن } \\
& \text { أبي شيبة ثنا يوسف بن يعقوب الصفار أنا علي بن عثام عن سعير بن الخمس عن مغيرة عن } \\
& \text { إبراهيم عن علقمة عن عبد الله قال: سئل النبي -صلى الله عليه وآله وسلم- عن الوسوسة } \\
& \text { فقال: "صريح الإيمان" . هذا حديث حسن صحيح غريب من الإفراد أخرجه مسلم عن } \\
& \text { الصفار فوافقناه بعلو، وليس لسعير لا ولعلي ولا للصفار في صحيح مسلم سواه. توفي في ثاني } \\
& \text { عشر صفر سنة اثنتين وأربعين وسبعمائة, رحمه الله تعالى. }
\end{aligned}
$$

Hadis ini disebutkan secara lengkap baik matan maupun sanadnya, dan terlihat jelas tentang status hadisnya yang dinilai hasan garib. Hadis ini 
disebutkan dalam kitab Sabih Muslim dan kitab al-Mustakbraj ala Sabih al-Imam Muslim. ${ }^{40}$

Apabila dibandingkan dengan Kitäb al-Rijäl versi Syiah tentang kualitas hadisnya sangat sulit ditemukan persamaan maupun perbedaannya karena Kitäb al-Rijal versi Syiah hanya menyebutkan para periwayat hadis tanpa menyebutkan hadis-hadis yang menjadi pendukung terhadap kedabitan periwayat, keadilan, dan pujian terhadap para periwayat. Kitäb al-Rijäl versi Syiah ini berbeda dengan Kitäb al-Rijäl versi Sunni. Dalam Kitäb al-Rijäl versi Sunni akan ditemukan hadishadis yang diangkat untuk mengangkat derajat kebaikan para periwayat hadis seperti kitab Ahwäl al-Rijäl, Ilmur Rijäl, al-Tlal wa Ma'rifat al-Rijäl dan lain-lain.

\section{Refleksi Studi Hadis dalam Tradisi Keilmuan}

Sebagai refleksi untuk mengetahui penyusunan dua kitab tersebut di atas maka penulis menggunakan pendekatan historis yaitu melihat bagaimana kitab tersebut disusun. Sebagai kerangka teori bahwa pendekatan historis adalah suatu pendekatan dengan melihat kesejarahan. Pemahaman terhadap sejarah pemikiran, politik, sosial dan ekonomi dalam hubungannya dengan pengarang dan isi naskah yang sedang dibahas menjadi suatu keniscayaan. Para orientalis menggunakan pendekatan historis dengan memadukan beberapa pendekatan sekaligus, yaitu kritik naskah (texstual criticism), kritik narasumber (literary atau source criticism), kritik ragam atau corak tulisan (form), kritik penyuntingan (redaction), dan kritik periwayatan (traditional/ transmission criticism). Penerapan metode-metode ini dicontohkan dengan sempurna oleh Miklos Muranyi dalam bukunya: Ein altes fragment medinensischer Jurisprudenz aus Qairawan, aus dem Kitab alHagg des Abd al-Ariz b. Abd Allah b. Abd Salama al-Magissun(st. 164/780781) cetakan Stuttgart, 1985; artikel Harald Motzki, "Des Fiqh des Zuhri: de Quellen problematik," dalam jurnal Der Islam no. 68 (1991), hlm. 1-44; dan Andreas Gorge dalam disertasinya, Das Kitab al-Amwal des Abu Ubaid al-Qasim b Sallam: entstehung und Werkuberliegerung (Univ. Hamburg, 20001). ${ }^{41}$

Pendekatan historis adalah mempertimbangkan kondisi historis-empiris pada saat suatu hadis itu disampaikan oleh Nabi SAW. Pendekatan historis bisa diartikan sebagai pendekatan yang dilakukan dengan cara mengaitkan antara ide atau gagasan yang terdapat dalam hadis dengan determinasi-determinasi sosial dan situasi historis kultural yang mengitarinya. ${ }^{42}$

Kedua kitab tersebut disusun tentunya tidak terlepas dari sejarah silam yang melatarbelakangi disusunnya suatu kitab tersebut. Kemungkinan besar bahwa kitab Tazkirat al-Huffarh disusun sebagai upaya legitimasi dari seorang

\footnotetext{
${ }^{40} \mathrm{Abu}$ Nuaim al-Asbahaniy, Al-Musnad al-Mustakbraj 'ala al-Imam Muslim (Riyadh: Bait al-Akar al-Dawliyah, 1998), juz 1, 200.

${ }^{41}$ M. Alfatih Suryadilaga, Metodologi Syarah Hadis ..., 65.

${ }^{42}$ Said Agil Husin Munawwar, Abdul Mustaqim, Asbabul Wurud: Studi Kritis Hadis Nabi: Pendekatan Sosio-Historis-Kontektual (Yogyakarta: Pustaka Pelajar, 2000), 26.
} 
pengarang terhadap tokoh-tokoh para periwayat dan penghafal hadis yang notabene mereka adalah dari kalangan sahabat, tabi'in, dan tabi'u tabi'in dan seterusnya.

Selain itu, seorang pengarang kitab Tazkirat al-Huffarb yaitu al-Zahabi adalah selain sebagai ahli hadis, juga sebagai ahli sejarah yang mengarang kitab Tãrikh al-Isläm. Maka sangat dekat sekali upaya pengarang untuk membuktikan kehebatan orang-orang Islam pada masa Nabi SAW dan kalangan sahabat dan seterusnya.

Dalam studi kitab hadis, kitab Tazkirat al-Huffazh karya al-Zahabi dan Kitab Rijal karya Dawud al-Hulli termasuk dalam kategori kitab Mu'jam atau alJuz'u karena disusun secara sistematis dengan mengurutkan para periwayat hadis berdasarkan huruf hija'iyyah dan juga termasuk dalam kitab Musnad karena disusun pula berdasarkan para periwayat hadis. Kitab Musnad yang dikenal adalah kitab Musnad Ahmad bin Hanbal, Musnad Abu Hanifah, Musnad alBazzar dan Musnad Ibnu Rahawaih dan lain-lain. ${ }^{43}$

Adanya kitab Taఇkirah al-Huffazh disusun dengan sistematika yang sangat detail dan terperinci sesuai huruf hijaiyyah. Begitu tertib dan terukurnya apa yang dilakukan pengarang dalam rangka menginformasikan kepada mereka sarjana Muslim dan sarjana Barat tentang kridibilitias dan kekuatan hafalan para sahabat sekalipun banyak kritikan akan keadilan para sahabat. ${ }^{44}$ Abu Hurairah adalah Sahabat Rasulullah yang banyak meriwayatkan hadis. Hadis-hadis yang berhasil diriwayatkan sekitar 5.374 hadis. Generasi sahabat adalah orang-orang yang menerima ajaran Islam langsung dari Nabi SAW. Mereka adalah orang-orang yang menyaksikan turunnya Alquran. Tanpa generasi sahabat orang-orang tidak bisa mengetahui sedikitpun tentang Islam. ${ }^{45}$

Selain itu sebagai asumsi dasar dari mereka adalah bahwa Abu Hurairah tidak diterima hadisnya oleh Ibnu Abbas dan Aisyah, bahkan menuduh sebagai pendusta. Jika seperti itu kenyataannya, berarti ungkapan Az-Zahabi yang menyebutkan bahwa Abu Hurairah sebagai penghafal hadis menjadi gugur dan hadis yang diriwayatkan Abu Hurairah dalam Shahih al-Bukhari, Shahih Muslim dan lain-lain menjadi tertolak. Sahabat lainnya, seperti Ibnu Syihab az-Zuhri yang dituduh oleh orang-orang Orientalis sebagai pemalsu hadis. ${ }^{46}$

Sedangkan para periwayat dalam Kitäb Rijäl versi Syi'ah, dilihat aspek historisnya adalah orang-orang yang berasal dari kalangan Rijal al-Hadits versi Syi'ah sebagaimana disebutkan dalam kitab al-Kafi al-Kulaini ${ }^{47}$ yang dianggap

43 Arif Wahyudi, "Mengurai Peta Kitab-Kitab Hadits (Kajian Referensi Atas KitabKitab Hadits)," dalam Jurnal Al-Ibkam Vol. 8, No. 1 (Juni, 2013), 4-5.

${ }^{44}$ Nur Fadlilah, "Keadilan Para Sahabat Nabi Dalam Perpektif Fuad Jabali," dalam Jurnal Mutawatir Vol. 2, No. 1 (June 2012), 113-114.

${ }^{45}$ Ali Mustafa Ya'qub, Kritik. Hadis (Jakarta: Pustaka Firdaus, 20011), 103.

${ }^{46}$ Ibid., 104.

${ }^{47}$ Kajian analisis Sanad dan Matan dilakukan untuk mengetahui jalur-jalur periwayatan hadis. Hasil penelitian Abd Somad menunjukan bahwa jalur periwayatan kitab al-Kafi al-Kulaini 
tidak diragukan lagi kedhabitan dan kualitas hafalannya dan semua periwayatan dinisbatkan kepada Ali bin Abi Thalib setelah Nabi Muhammad SAW. Dalam pandangan Syi'ah bahwa para Nabi dan Imam mempunyai otoritas tertinggi dalam upaya pencampaian ilmu. Sehingga keilmuan mereka tidak diragukan lagi. Pengetahuan tentang rijal al-Hadits, dari Imam Husain sampai kepada Imam Mahdi merupakan para pewaris ilmu dari Imam Ali dan Rasulullah SAW. ${ }^{48}$ Sekalipun demikian, al-Kulaini tidak mengklaim bahwa ada hadis-hadis yang dalam kitabnya, tidak semuanya sahih dan bersambung kepada para imam yang ma'shum. ${ }^{49}$ Pernyataan tersebut sangat relevan dengan Kitab Rijäl yang menjadi objek kajian dalam penelitian ini, karena di kitab tersebut ditemukan beberapa periwayat yang tidak terpercaya sebagaimana telah disebutkan dalam uraian di atas.

\section{Penutup}

Berdasarkan uraian di atas, dapat disimpulkan menjadi dua hal yaitu aspek persamaan dan aspek perbedaan. Pertama, aspek persamaannya, kitab Tadzkirat al-Huffarh karya al-Zahabi dan Kitab al-Rijal karya al-Hulli keduanya sama-sama membahas para periwayat hadis dari aspek kualitasnya yang meliputi keadilan dan ketercelaan para sahabat yang dikritik oleh para kritikus hadis, keduanya disusun berdasarkan abjad secara per-juz sebagaimana kitab Kamus atau kitab Mu'jam pada umumnya. Kedua, aspek perbedaan, kitab Tadækirat alHuffarb karya al-Zahabi menyebutkan kualitas para periwayat hadis dengan melihat beberapa hadis pendukung versi Sunni. Kitab al-Rijal versi Sunni akan mudah ditemukan hadis-hadis yang diangkat untuk mengangkat derajat kebaikan para periwayat hadis seperti kitab Ahwal al-Rijal, Ilm al-Rijal, al-Tlal wa Ma'rifah alRijäl dan lain-lain. Hal ini berbeda dengan dengan Kitäb al-Rijäl karya al-Hulli, kualitas hadisnya sangat sulit sekali untuk diidentifikasi secara utuh karena Kitäb al-Rijal hanya menyebutkan para periwayat hadis tanpa menyebutkan hadis-hadis yang menjadi pendukung terhadap kedabitan periwayat, keadilan, dan pujian terhadap para periwayat.

Studi kitab Taqkirat al-Huffazh disusun sesuai kitab Mu'jam dan kitab Musnad sebagai upaya legitimasi seorang pengarang terhadap tokoh-tokoh para periwayat dan penghafal hadis yang notabene mereka adalah dari kalangan sahabat, tabi'in, tabi'u al-Tabiin dan seterusnya. Al-Zahabi ingin membuktikan kehebatan para sahabat Nabi yang tidak diragukan lagi kredibilitas hafalan dan periwayatannya. Kitäb al-Rijäl versi Syi'ah juga ingin membuktikan kehebataan

disandarkan kepada Ali bin Thalib yang maksum dari dosa melebihi Rasulullah. Lihat Abd Somad, "Mengenal Referensi Hadits Syi'ah Kitab Al-Kafi Karya Imam Al-Kulaini (w.329H)," JURNAL USHULUDDIN Vol. XXI, No. 1 (2014), 7.

${ }^{48}$ Muhammad Alfatih Suryadilaga, "Hadis-hadis tentang Ilmu dalam Kitab al-Kafi alKulaini” dalam Disertasi UIN Sunan Kalijaga Yogyakarta 2008, 228.

${ }^{49}$ Wahyu Shifatur Rahmah, "Epistemologi Hadis: Sunni dan Syi'ah" dalam Tesis UIN Sunan Kalijaga Yogyakarta 2006, 129. 
para sahabat mereka dari kalangan rijäl al-Hadits sebagaimana terdapat dalam kitab Rijal terkenal yakni al-Kafi al-Kulaini yang dinisbatkan kepada Ali bin Abi Thalib.

\section{Daftar Pustaka}

Al-Asbahani, Abu Nuaim, Al-Musnad al-Mustakhraj 'ala al-Imam Muslim, Riyadh: Bait al-Afkar al-Dawliyah, 1998.

Al-Bukhari, Muhammad bin Isma'il bin Ibrahim bin al-Mughirah, Shabih alBukhari, Beirut: Dar al-Thuq al-Najah, 1422.

Al-Zahabi, Muhammad bin Ahmad bin Utsman, Al-Muqtani fi al-Sard al-Kuna, Al-Mamlakah al-Arabiyah al-Su'udiyah: Dar Ihya al-Turats al-Arabiyah, 1408.

, Kitab al-Kabair, Beirut: Dar al-Kutub, 1992.

, Tadzkirah al-Huffazh, Beirut: Dar al-Kutub al-Imiyah, 1998.

, Drail al-Taquid fi Ruwat al-Sunan wa al-Asanidi, Beirut: Dar al-Kutub alIlmiyah, 1990.

Azami, Mustafa, Memahami Ilmu Hadis: Telaah Metodologi dan Literatur Hadis, terj. Meth Kieraha, Jakarta: Lentera, 2003.

Al-Hulli, Taqiyyuddin al-Hasan bin Ali bin Dawud, Kitab al-Rijal, CD Maktabah asy-Syamilah Versi 3,48

Ali Humaid,Sa'ad bin Abdillah, Fatâwâ Haditsiyah, Riyadh: Dar Ulum al-Sunnah, 1999.

Al-Katani, Abdul Hai bin Abdul Kabir, Fibras al-Faharis wa Itsbat wa Mu'jam alMa'ajim wa al-Musyikhat wa al-Musalsalat, Beirut: Dar al-Ghurab al-Islami, 1982.

Al-Qazwini, Abu Abdillah Muhammad bin Yazid, Sunan Ibni Majah, Tp.,: Dar Ihya al-Turats, t.t.

Al-Sijistani, Abu Dawud Sulaiman bin al-Asy'ats, Sunan Abi Daud, Riyadh: Bait al-Afakr al-Dawliyah, t.t.

Al-Subki, Tajuddin bin Ali bin Abdillah al-Kafi, Tabaqatu al-Syafi'i al-Kubra, Tp.,: Dar Ihya al-Kutub al-Arabiyah, t.t.

Al-Tirmidzi, Muhammad bin Isa bin Saurah al-Tirmidzi, Sunan al-Tirmidri, Riyadh: Maktabah al-Ma'arif, t.t.

Amin, Samsul Munir, Sejarah Peradaban Islam, Jakarta: Amzah, 2010.

Ash-Shiddieqy, TM. Hasbi, Sejarah dan Pengantar Ilmu Hadis, Semarang: Pustaka Rizki Putra, 2010. 
Mahdi, Aiman Mahmud, Al-Jarh wa al-Ta'dîl Bain al-Nadzariyah wa al-Tathbîq, CD Maktabah al-Syamilah, versi 3.28.

Munawwar, Said Agil Husin, Abdul Mustaqim, Asbabul Wurud: Studi Kritis Hadis Nabi: Pendekatan Sosio-Historis-Kontektual, Yogyakarta: Pustaka Pelajar, 2000.

Shalih, Subhi, Membahas Ilmu-ilmu Hadis, terj. Tim Pustaka Firdaus, Jakarta, Pustaka Firdaus, 2013.

Suryadilaga, M. Alfatih (ed), Studi Kitab Hadis, Yogyakarta: Teras, 2009.

Thahan, Mahmud, Metode Takbrij dan Penelitian Sanad Hadis, terj. Ridwan Nasir, Surabaya: Bina Ilmu Offset, 1995. , Taisir Musthalah al-Hadits, Beirut: Dar al-Fikr, t.t.

Ya'qub, Ali Mustafa, Kritik Hadis, Jakarta: Pustaka Firdaus, 20011.

\section{Jurnal}

Amin, Kamaruddin," The Reliability Of The Traditional Science Of Hadith: A Critical Reconsideration" Jurnal Al-Jami’ah, Vol. 43, No. 2, 2005.

Fadlilah, Nur. "Keadilan Para Sahabat Nabi Dalam Perpektif Fuad Jabali." Jurnal Mutawatir Vol. 2, no. 1, June 2012.

Rohmansyah, "Konsep Jihad dalam Kutub at-Tis'ah (Studi Maudhui)" Jurnal AlMajaalis, Vol. 3, No. 2, Mei 2016.

Somad, Abd. "Mengenal Referensi Hadits Syi'ah Kitab Al-Kafi Karya Imam AlKulaini (w.329H)." JURNAL USHULUDDIN Vol. XXI, no. No. 1 (2014).

Shalahudin, Marwan, "Historiografi Ulama Klasik dalam Tabaqat" Jurnal Kalimah Vol. 12, No. 1, Maret 2014.

Suchimin. "Telaah Pemikiran Hadis Mahmud Abu Rayyah Dalam Buku 'Adwa Ala Al-Sunnah Al-Muhammadiyah."' Hunafa: Jurnal Studia Islamika Vol. 9, No. 2, 2012.

Wahyudi, Arif. "Mengurai Peta Kitab-Kitab Hadits (Kajian Referensi Atas Kitab-Kitab Hadits)." Al-Ibkam Vol. 8, No. 1, 2013.

Yahya, Agusni, "Pendekatan Hermeneutik dalam Pemahaman Hadis (Kajian Kitab Fath Bari karya Ibnu Hajar al-Asqalani), dalam Jurnal Ar-Raniry: International Journal of Islamic Studies, Vol. 1, No. 2, Desember 2014. 